\title{
Cloud IaaS Enterprise Architecture Design on Multiplatform Integrated Information System using Cloud Ecosystem Reference Model and TOGAF
}

\author{
Setiyo Widayat ${ }^{1}$, MS Suksrisno Mardiyanto ${ }^{2}$ \\ ${ }^{1}$ Magister Informatika, Sekolah Teknik Elektro dan Informatika, Institut Teknologi Bandung, Bandung. \\ Email: setiyowidayat@mail.com \\ ${ }^{2}$ Magister Informatika, Sekolah Teknik Elektro dan Informatika, Institut Teknologi Bandung, Bandung. \\ Email: msukrisno@informatika.org
}

\begin{abstract}
Currently Information Technology is increasingly needed by many organizations. Implementation of inappropriate IT in the organization will be a burden, even can hinder the development if not in accordance with the vision and mission of the organization. Weill and Ross also stated, 48 percent of companies that do IT investment cannot increase the expected value. A solid foundation in the execution process of IT implementation plays an important role in determining the success or failure of the company to achieve the desired goals. To build a solid foundation on the execution process of IT implementation, one of the important things to note is Enterprise Architecture (AE). Enterprise architecture provides a long-term view of the processes, systems and technologies in the company, so there is a harmony between business and IT both for now and for the future to achieve the desired goals. Currently the use of cloud computing technology increasingly used in organizations. Organizations typically have a variety of different platform integrated applications that are used to support their business processes. There are many frameworks used to build AE, but there is no AE framework specifically addressing AE design on cloud computing and supports multiplatform and cloud-based IaaS. This paper discusses the use of TOGAF and CERM to educational institution that have many integrated multiplatform applications. AE design that was built is validated by using Enterprise Realization Score Card (EARS) to assess whether it can be implemented well in the organization.
\end{abstract}

Keywords: Enterprise Architecture, Multiplatform, IaaS, TOGAF, CERM

\begin{abstract}
Abstrak
Saat ini Teknologi Informasi semakin dibutuhkan oleh banyak organisasi. Penerapan TI yang tidak sesuai dalam perusahaan justru akan menjadi beban, bahkan dapat menghambat perkembangan apabila tidak sesuai dengan visi dan misi perusahaan. Weill dan Ross juga menyatakan, 48 persen perusahaan yang melakukan investasi TI tidak dapat meningkatkan value yang diharapkan. Pondasi yang kokoh dalam proses eksekusi penerapan TI memegang peran penting dalam menentukan berhasil atau tidaknya perusahaan mencapai tujuan yang diinginkan. Untuk membangun pondasi yang kokoh pada proses eksekusi penerapan TI, salah satu hal penting yang perlu diperhatikan yaitu Arsitektur Enterprise. Arsitektur Enterprise memberikan pandangan jangka panjang proses, sistem dan teknologi pada perusahaan, sehingga terdapat keselarasan antara bisnis dan TI baik untuk saat ini maupun masa yang akan datang demi mencapai tujuan yang diinginkan. Saat ini penggunakan teknologi komputasi awan semakin banyak digunakan pada organisasi. Organisasi biasanya memiliki berbagai macam aplikasi berbeda platform yang terintegrasi yang digunakan untuk mendukung proses bisnisnya. Ada banyak kerangka kerja yang digunakan untuk membangun AE, namun belum ada kerangka kerja AE yang khusus membahas perancangan AE pada komputasi awan dan mendukung multiplatform dan berbasis cloud IaaS. Paper ini membahas mengenai penggunaan TOGAF dan CERM pada penerapan TI untuk intstitusi pendidikan yang memiliki banyak aplikasi terintegrasi dan multiplatform. Rancangan AE yang dibangun dilakukan validasi dengan menggunakan Enterprise Realization Score Card untuk menilai apakah dapat di implementasikan dengan baik pada organisasi.
\end{abstract}

Kata Kunci: Arsitektur Enterprise, Multiplatform, IaaS, TOGAF, CERM

\section{Introduction}

According to Weill and Ross, companies / enterprises that invest IT to support their business processes have relatively higher profits, faster market responses, and more value than their competitors. IT implementation in enterprise makes enterprise more efficient in achieving business strategy, and tends to be more adaptable to change. But not all companies that invest IT get the desired benefits. Implementation of inappropriate IT in the company will be a burden, even can hinder the development 
if not in accordance with the vision and mission of the company. Weill and Ross also stated, 48 percent of companies that do IT investment cannot increase the expected value. A solid foundation in the execution process of IT implementation plays an important role in determining the success or failure of the company to achieve the desired goals.

To build a solid foundation on the execution process of IT implementation, one of the important things to note is Enterprise Architecture (Weill and Ross, 2006). According to Weill and Ross (2006), Enterprise Architecture is the organizing of business processes and IT infrastructure, in order to integrate and standardize the company's operational activities. Enterprise architecture provides a long-term view of the processes, systems and technologies in the company, so there is a harmony between business and IT both for now and for the future to achieve the desired goals. In Enterprise Architecture, it is also discussed about the integration of enterprise IT systems, so that each connected sub-system can collaborate with each other.

Changes in business processes within the organization are always happening, while the IT department must respond quickly. According to Liu (2017), traditional IT architecture will be difficult to adapt to change, because small changes in one component only, will take a long time if the components are interconnected with others, which will cause operational activities hampered. For that is where the role of Enterprise Architecture by using Cloud Ecosystem Reference Model (CERM). In CERM, there is an abstraction of the foundation in initiating an architecture and business solutions within an enterprise. In addition CERM ensures consistency and is easy to apply with Enterprise Architecture framework like TOGAF.

In this study the authors try to build a model of architecture based Cloud IaaS to support business processes at the Educational Organization naming XYZ which has several integrated applications and different platforms. In the execution, the authors adopt the stages of TOGAF ADM. The end result of this research is the recommendation of Enterprise Architecture model that supports multiplatform and cloud-based IaaS. Good Enterprise Architecture is required to avoid failure at the time of execution of IT application at XYZ organization.

\section{Backgrounds}

There are three important aspect in this study which are architecture enterprise, TOGAF, and cloud ecosystem reference model.

\subsection{Architecture Enterprise}

According to Weill and Ross (2006), Enterprise architecture is the organization between business processes and IT infrastructure, reflecting the requirements of integration and standardization of the company's operating model. Enterprise architecture provides a long-term view of enterprise processes, systems and technologies so that an IT project within a company can be capabilities, not just urgent needs. Enterprise architecture is created at least to address two issues:

1. The Complexity of Systems, Organizations / Companies are increasingly in need of more investments to build IT systems,

2. Alignment between Business and IT is bad, Organizations / Companies are increasingly difficult to harmonize expensive IT Systems with their growing business needs.

\subsection{TOGAF}

TOGAF is a framework for building an Enterprise Architecture within an organization. The TOGAF framework provides an approach to design, plan, implement, and manage IT Architecture in an organization or enterprise (Pamela and Severin, 2017). In TOGAF IT architecture is modeled into 4 architecture domains, Business, Application, Data, and Technology. The business architecture defines the organization's business strategy, governance, organization and business processes. The application architecture defines the blueprints of systems that have been and will be built, the interaction between the application systems, as well as the relationships between the main business processes of the organization with the framework in performing the business functions of the organization. Data architecture describes both physical and logical data structures and data source 
management. Architecture Technology describes the tentacles of hardware (Hardware), Software (Software), as well as network infrastructure needed to support the main applications running within the organization.

ADM's Architecture Development Method, is used to build Enterprise Architecture that aligns between Business and Information Technology used in organizations (Pamela and Severin, 2017). TOGAF ADM provides a detailed description of the stages in the process of developing Enterprise Architecture. These processes can be both iterative and repetitive. As a core component, TOGAF $\mathrm{ADM}$ provides a range of iterative processes ranging from compiling architecture, transition, to managing the process of architectural realization. TOGAF ADM consists of ten phases: Preliminary Phase, Architecture Vision, Business Architecture, Information Systems Architectures, Technology Architecture, Opportunities and Solutions, Migration and Planning, Implementation Governance, Architecture Change Management, and Requirements Management.

\subsection{Cloud Ecosystem Reference Model}

The Cloud Ecosystem Reference Model is an abstract base in the instantiation of an enterprise's business architecture and solutions (TOGAF ADM, 2017). CERM defines a flexible and collaborative enterprise cloud ecosystem. CERM also provides experience for effective digital customers in securely sharing business information regardless of their base data location. The Cloud Ecosystem Reference Model ensures consistency and deployment of the Cloud Computing Service in a variety of Enterprise Architecture management frameworks (TOGAF ADM, 2017).

The Cloud Ecosystem Reference Model can be considered as an extension of an Enterprise Architecture Model. This model can be used to define an architecture in scenarios of existing and existing Cloud Enterprise Ecosystems using Solution Building Blocks (SBBs) in an organization. there are 4 major entities that are in Cloud Computing Ecosystem namely:

1. Cloud Service Provider: is an organization or entity that utilizes and distributes Cloud-based services to interested parties.

2. Cloud Service Consumer: is an individual or an organization that works with Cloud service providers to use their Cloud-based services.

3. Cloud Service Broker: is an entity that negotiates the relationship between Cloud service providers and Cloud service consumers as well as managing the performance, delivery and use of Cloud-based services.

4. Cloud Service Auditor: is a cloud services auditor independently assesses and audits the performance, security, operation of the Information System and Cloud services from Cloud implementation.

Cloud Service Developer: an individual or organization that develops Cloud based services. Development of Cloud Ecosystem Reference Model Enterprise Architecture can refer to the stages of TOGAF ADM.

\section{Methods}

In this study, the method used is Design Science Research Methodology (DSRM) proposed by Ken Peffers et al. (2000) .DSRM focuses on the development of methodology for research in the field of Information Systems. The DSRM methodology has 6 stages: Problem identification and Motivation, Goal Setting, Design and Development, Demonstration, Evaluation, and Communication. The image below is a chart of the DSRM Methodology process. 


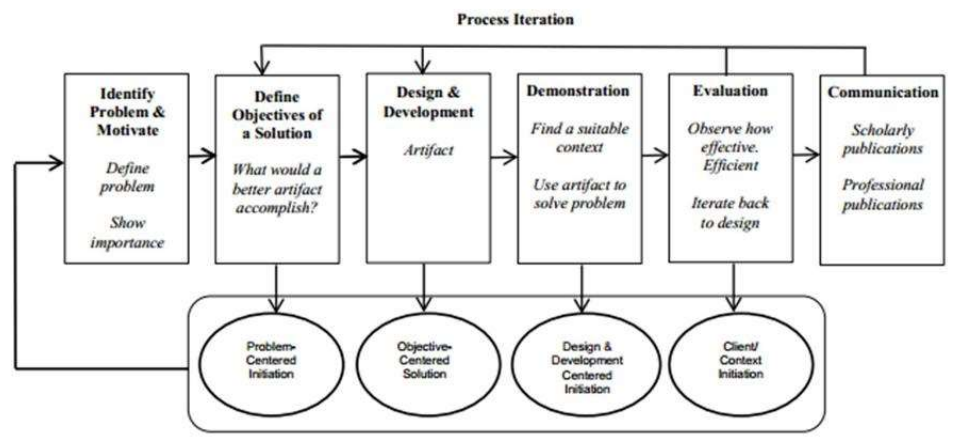

Figure 1. DSRM Methodology Process

Source: Peffers Ken et al, A Design Science Research Methodology for Information Systems Research, Journal of Management Information Systems, 2000

\section{Result and Discussion}

The vision architecture describes the principles of architecture and data principles. The following principles of architecture and principles of data on $\mathrm{XYZ}$ organization:
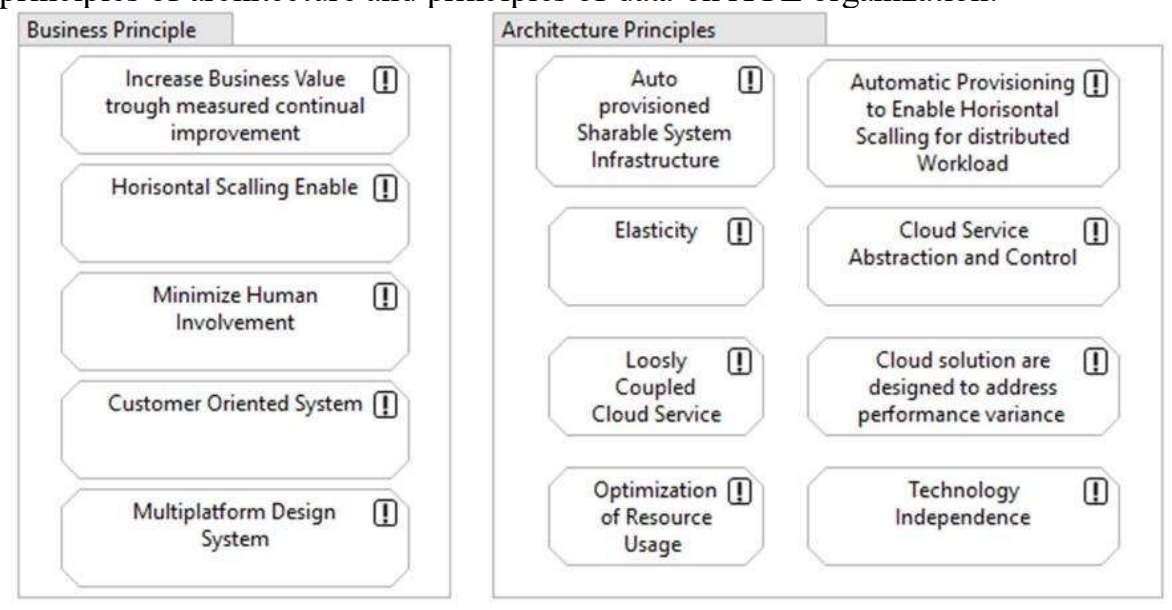

Principle [1]

Figure 2. Business and Architecture Principle

1. Increase Business Value through measured improvement

Enterprise architecture that will be built should increase the value of business within the organization.

2. Horizontal Scaling Enable

Enterprise architecture that will be built should be able to adapt to business changes.

3. Minimize Human Involvement

Enterprise Architecture to be built should be able to minimize the human resources used.

4. Customer Oriented System

Enterprise architecture to be built should be customer oriented.

5. Multiplatform Design System

The Enterprise architecture to be built should be designed for different platform systems.

Business architecture describes the business processes of the organization. Business business processes will be translated into services provided by the XYZ organization which are intended for all stakeholders within organization. Here is a figure of Business Architecture target (target) to be built. 


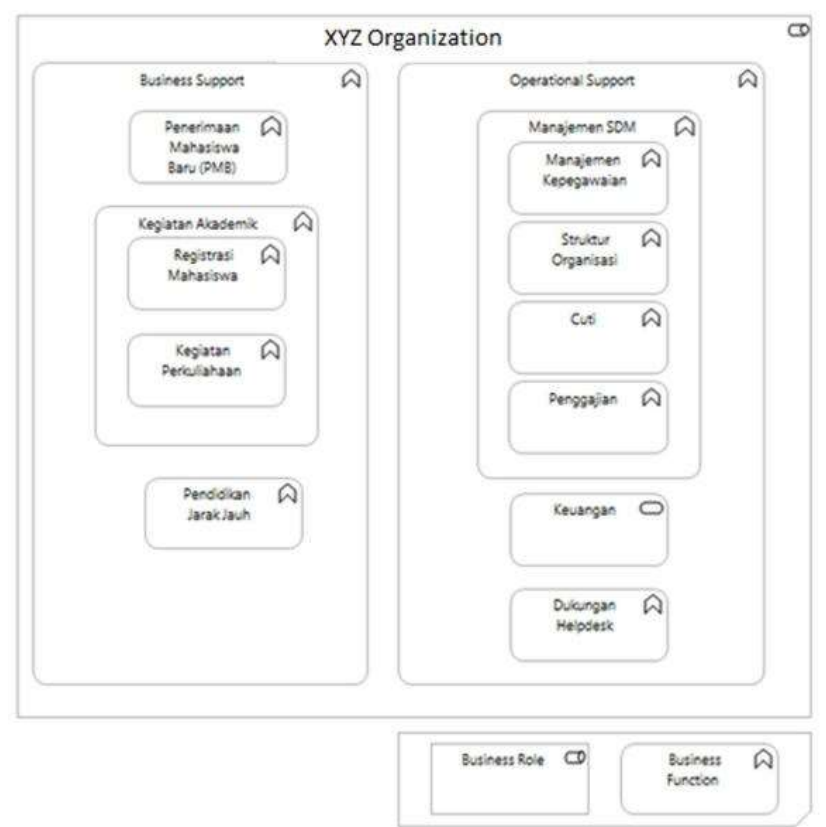

Figure 3. Business Process form XYZ Organization

Information System Architecture describes the list of future Information System for XYZ organization.

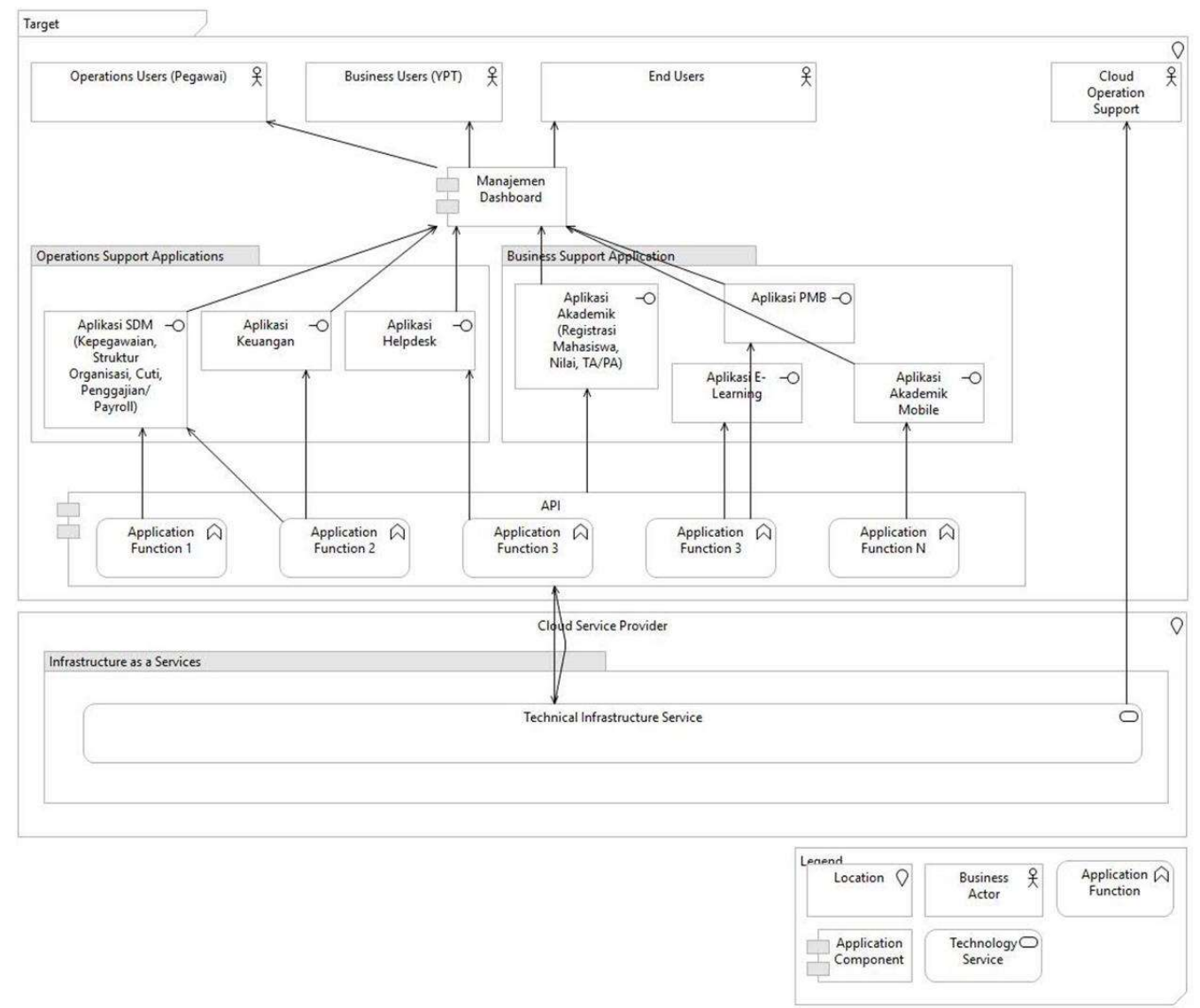

Figure 4. Application Architecture for XYZ Organization 
Applications are divided into specific functions that can be used repeatedly by different applications. These functions are accessed by each application via REST API so it supports mobile platform like android and IOS. The applications used are divided into two categories, Applications that support the main business processes (Business Support Applications) and applications that support operational activities (Operations Support Applications). In addition, built a web portal as the entrance of the user in accessing the applications they want. For example if previous business users and operational users access different applications, then with the new application architecture both users can access the same Web Portal, and then directed into the application that they can access in accordance with the role given.

Technology Architecture describes the list of future Information Technology Architecture for XYZ organization.

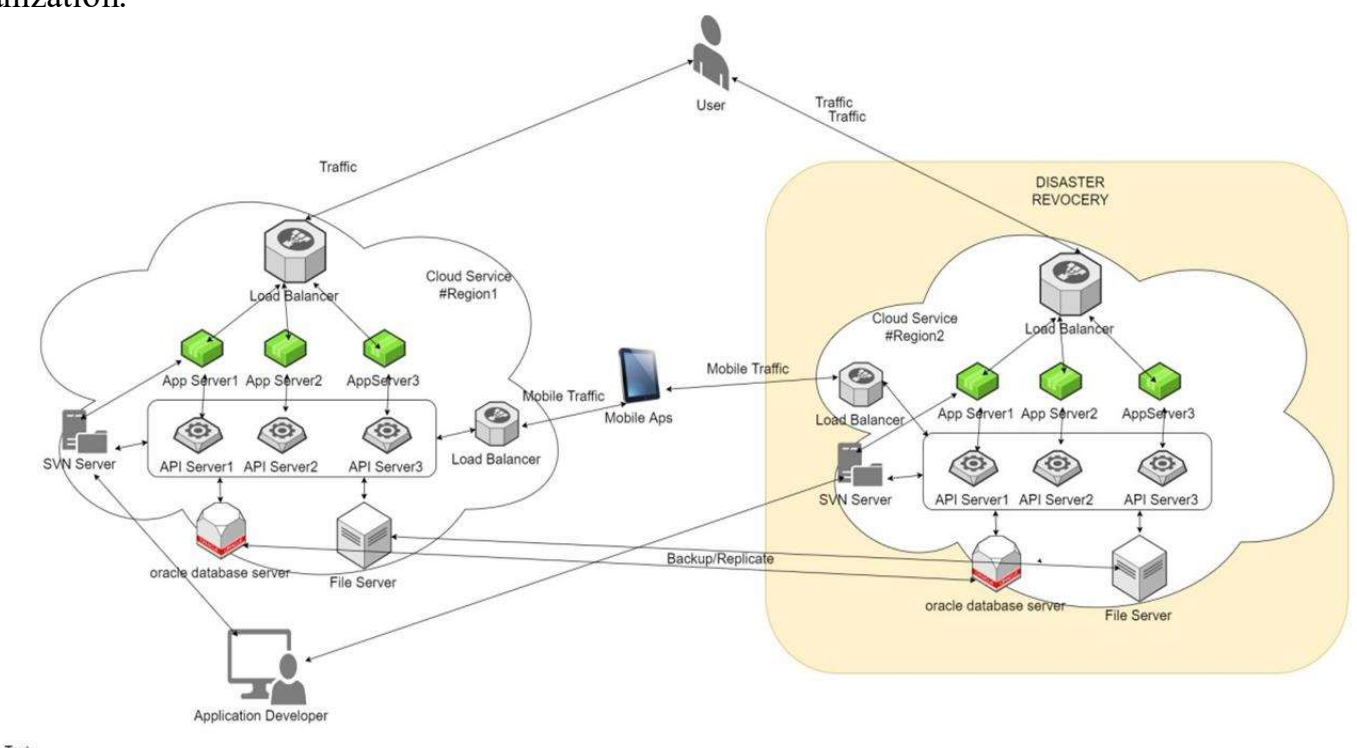

Figure 5: Technology Architecture for XYZ organization

The new Technology Architecture is designed to better adapt to changing the need for increased IT infrastructure capacity by moving multiple IT Infrastructure services into cloud service. Some services migrated into the cloud are network services, storage space, application servers, so it is expected to be easier in increasing the capacity of the service. There is also a Disaster Recovery mechanism when a system failure occurs. Disaster Recovery System is a server duplication of the main server placed in different locations / regions.

The built $\mathrm{AE}$ is validated using the Enterprise Architecture Realization EARS Scorecard that assesses AE based on product, acceptance, and scope aspects. The following AE validation results are:

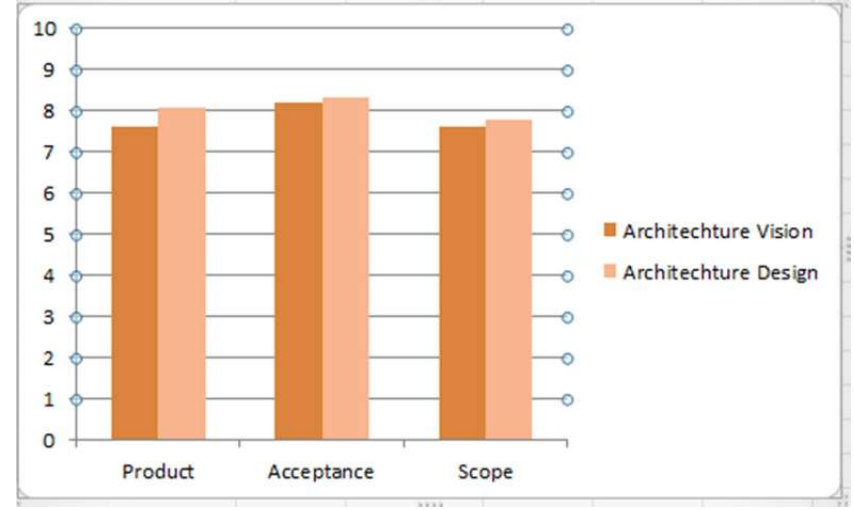

Figure 6. EARS Validation 


\section{Conclusion}

Based on the results of this study, it can be concluded some things about the design of Enterprise Cloud IaaS Architecture using TOGAF and CERM are as follows:

1. Cloud-based Enterprise Architecture IaaS successfully built with reference stages on TOGAF $\mathrm{ADM}$

2. Cloud IaaS Model Architecture successfully built with case studies in the XYZ Organization engaged in education can provide information about how to develop the IT architecture, so it can be used as a reference model for various other educational institutions and companies that will build a supporting architecture multiplatform with Cloud-based IT infrastructure.

\section{References}

J. Schmidt Pamela, V. Grabski Severin, Proposing a Cloud Computing Capability Maturity Model, http://jebcl.com/symposium/wp-content/uploads/2015/09/ID6_Grabski_Schmidt_Cloud-CapabilityMaturity-Model.pdf, (diakses tanggal 11 Juni 2017).

J.W. Ross, P. Weill, and D. Robertson, Enterprise Architecture as Strategy: Creating a Foundation for Business Execution, Harvard Business School Press, 2006.

Open Group Standard, TOGAF ADM, http://pubs.opengroup.org/architecture/togaf9-doc/arch/toc- pt2.html (diakses tanggal 21 Juli 2017).

Peffers Ken dkk, A Design Science Research Methodology for Information Systems Research, Journal of Management Information Systems, 2000. 